\title{
Analysis of cat diet across an urbanisation gradient
}

\section{Aleksandra M. Piontek ${ }^{1}$ (D) Ewa Wojtylak-Jurkiewicz ${ }^{2} \cdot$ Krzysztof Schmidt $^{3}$ (D) Agnieszka Gajda $^{4}$ (D) Maciej Lesiak $^{5}$. Izabela A. Wierzbowska ${ }^{6}$ CD}

Published online: 13 June 2020

(C) The Author(s) 2020

\begin{abstract}
The domestic cat is a widespread and abundant predator that negatively impacts a wide range of species. However, the predation activity and prey type of free-ranging cats may vary between areas with different levels urbanisation. Previous analyses of cat diet have used differing techniques to measure predation that often differ with one another. Given the variability in these methods we hypothesised that cats in rural areas will have a more diverse diet than in urban areas and their predation rate may be higher than those in the urban sites. Moreover, we hypothesized that the diet of urban cats should be highly influenced by anthropogenic food. We selected sites across a rural-to-urban gradient and used three methods of analysis to determine prey in the diet (cat stomachs, cat scats, and prey brought home). We collected 81 stomachs, 409 scats, and 337 prey items of free-roaming cats from six study sites located in southern and eastern Poland. We found seasonal and habitat related differences in prey composition. The proportion of scats and stomachs containing vertebrate varied from $17 \%$ in urban areas to $79 \%$ in one of the rural areas. Small rodents were the dominant prey category, followed by birds and soricomorphs. Anthropogenic food was found to be an important part of urban cats' diet, but its significance decreased with a decrease in urbanisation level. Both predation rate and prey diversity were highest in rural areas. While diet analysis provided a better estimation of cat predation rate, the detailed prey examination provided better insight into less common taxa killed by the cats, such as reptiles and small mustelids. Our results contribute to the discussion about the risks associated with the activity of free ranging cats especially in areas with high conservation values.
\end{abstract}

Keywords Diet analysis $\cdot$ Domestic cat $\cdot$ Felis catus $\cdot$ Free-ranging $\cdot$ Urban wildlife

Electronic supplementary material The online version of this article (https://doi.org/10.1007/s11252-020-01017-y) contains supplementary material, which is available to authorized users.

Izabela A. Wierzbowska i.wierzbowska@uj.edu.pl

1 Faculty of Biology, Institute of Environmental Sciences, Jagiellonian University, 7 Gronostajowa Str, 30-387 Kraków, Poland

2 National Research Institute of Animal Production, 1 Krakowska Str., 32-083, Balice, Poland

3 Mammal Research Institute, Polish Academy of Sciences, 17-230 Białowieża, Poland

4 Institute of Urban and Regional Development, 45 Targowa Str, 03-728 Warszawa, Poland

5 "KABAN" Maciej Lesiak, os. Albertyńskie 1-2/125, 31-851 Kraków, Poland

6 Institute of Environmental Sciences, Faculty of Biology, Jagiellonian University, 7 Gronostajowa Str, 30-387 Kraków, Poland

\section{Introduction}

One of the most detrimental invasive species in the world is the domestic cat (Felis catus) (Doherty et al. 2016), with welldocumented negative impacts noted in numerous ecosystems, including oceanic islands (Faulquier et al. 2009, Medina and Nogales 2009, Medina et al. 2011), coastal ecosystems (Risbey et al. 1999), and urban ecosystems (Baker et al. 2005). Specifically, domestic cats that have access to the outdoors or are free-ranging harbour a number of diseases that affect human and wildlife health (Lepczyk et al. 2015; Chalkowski et al. 2019), are opportunistic predators that can easily switch prey (Bonnaud et al. 2011), hunt wild prey even if it is scarce (Dickman and Newsome 2015), and kill billions of birds and mammals every year (Loss et al. 2013). Furthermore, cat foraging behaviour can vary seasonally and they can exploit different food resources including wild animals, waste food, carcasses of large animals and even plant material (Lepczyk et al. 2015; Lepczyk and Duffy 2018). 
Because of their predatory nature, feral and free-ranging cats are a major cause of native species populations declines (Medina et al. 2011; Moseby et al. 2015) and local extinctions on oceanic islands (Álvarez-Castañeda and Ortega-Rubio 2003; Dowding and Murphy 2001) as well as in continental locations (Loss and Marra 2017). Free-ranging cats, whether stray or owned, in urban habitats are often considered by the general public to be less dangerous for wildlife than feral cats living in natural habitats (Farnworth et al. 2011, Walker et al. 2017). Moreover, the majority of cat prey species are usually small mammals (Brickner-Braun et al. 2007, Tschanz et al. 2011, Krauze-Gryz et al. 2012) and characterised by high population densities and reproductive rates. Thus, local predation of cats may not drastically influence their population size (Nelson et al. 2005). However, due to large cat population densities in certain areas, e.g. city cores, even a low predation rate of individuals may negatively affect less common species like songbirds (van Heezik et al. 2010, Loss and Marra 2017). The home ranges of urban cats tend to include more gardens and other green spaces than can be expected by their availability (Thomas et al. 2014), hence increasing the risk of encountering potential prey.

In Poland there are over 6 million cats, and $31 \%$ of households own at least one cat (FEDIAF Facts \& Figs. 2016). The majority of the cat population can be considered free-ranging, as it is a common practice to allow even owned cats to roam freely in the neighbourhood. Therefore, cat predation on wildlife can have significant effects in both urban and rural areas. Cats are also reported to roam the areas of national parks, likely having negative impacts on local conservation goals (Wierzbowska et al. 2012). However, there is insufficient knowledge about the impact domestic cats exert on habitats with differing urbanisation levels. Cats in urban areas are more likely to be confined in households but are characterised by high population densities (Flockhart et al. 2016). In contrast, rural cats may have lower population densities but spend more time outside and have bigger home ranges (Metsers et al. 2010).

A previous study in Poland examining the prey composition of domestic cats in relation to urban vs. rural location and season showed that urban cats take more birds than rural cats (Krauze-Gryz et al. 2017). However, the study was based only on recording prey brought home, which is known to bias the rate and frequency of prey species as compared to analysis of scats and stomach contents (Krauze-Gryz et al. 2012, Széles et al. 2018). Therefore, proper understanding of the diverse pressure of domestic cats on wildlife in habitats with differing human populations requires applying the same methods across the gradient of urbanisation. Given the limitations of this previous work, we hypothesised that cats in rural areas will have a more diverse diet than in urban areas and their predation rate may be higher than those in the urban sites. Moreover, we hypothesized that the diet of urban cats should be highly influenced by anthropogenic food.

\section{Materials and methods}

\section{Study area}

We collected material from six different study sites located in Poland representing various levels of urbanisation and land use (Fig. 1.). To classify our study sites into zones we used an urban transect method (Duany and Talen 2002) modified for Polish conditions and based on Land and Building Registry datasets (two main land use types and functions of buildings were used) (Gajda and Pancewicz 2018) (Online Resource 1). To simplify categories we have classified zones $\mathrm{T} 1$ and $\mathrm{T} 2$ as rural, $\mathrm{T} 2.5$ as suburban (transition zone between rural and urban) and T3, T4, T4.5 and special zones as urban (with T4.5 as high density housing complexes). The calculated characteristic parameters of each category are presented in Table 1.

Kraków $\left(50^{\circ} 03^{\prime} 4^{\prime \prime} \mathrm{N}, 19^{\circ} 56^{\prime} 1^{\prime \prime} \mathrm{E}\right)$ is the second largest city in Poland, with a human population of 759,131 residents (Statistics Poland 2018). The city is situated between different macro-regions i.e., the Kraków-Częstochowa Upland, the Sandomierz Basin, the Nida Basin and the Western Beskidy Foothills. Kraków is characterized by differentiated land cover (Fig. 2a) comprised of built up areas, agricultural lands, green patches (mainly parks, orchards, meadows and woodlots) and water courses. Forests constitute $11 \%$ of the total city land with patches of oak - hornbeam and mixed coniferous forests. The centre of the city is crossed by the Vistula River, the largest Polish river, which provides a migration corridor for many species from west to east. The city core is strongly urbanised while the outskirt districts are mostly composed of

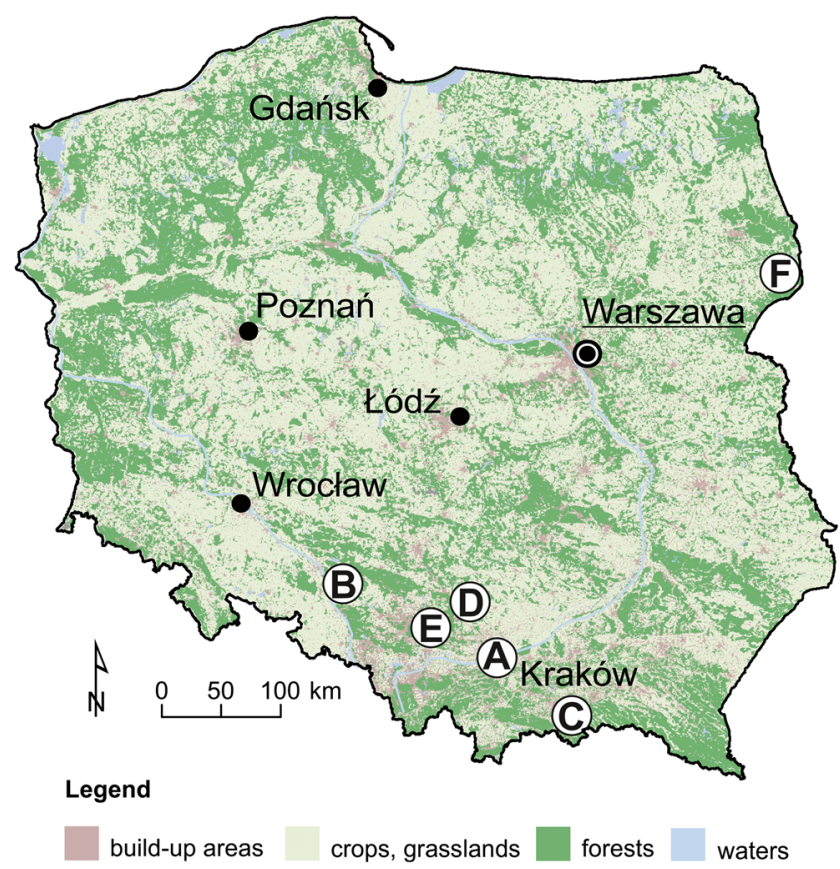

Fig. 1 Geographic locations of study sites. A - Kraków, B - Strzelce Opolskie, C - Krynica-Zdrój, D - Ojców, E - Czerna, F - Białowieża 
Table 1 Main spatial indicators of the urbanisation level of study areas (Gajda and Pancewicz 2018)

\begin{tabular}{llll}
\hline & Rural & Suburban & Urban \\
\hline Zones & $\mathrm{T} 1, \mathrm{~T} 2$ & $\mathrm{~T} 2.5$ & $\mathrm{~T} 3, \mathrm{~T} 4, \mathrm{~T} 4.5$, special zones \\
Floor space index (average) & 2 & 10 & 70 \\
Population density (per km ${ }^{2}$ ) & 100 & 500 & 15,000 \\
Average distance between buildings (m) & 50 & 20 & 15 \\
\hline
\end{tabular}

blocks of flats and detached houses with patches of green areas like parks, gardens and meadows. Because of gradually growing urbanisation, many villages which were previously situated near city borders are now transformed into suburban areas with remaining small patches of agricultural fields and meadows. Within the city there are several nature protection

Fig. 2 The locations of study sites. Colour dots represent locations of sampling sites in urban, suburban and rural areas. a Kraków, b Strzelce Opolskie, c Krynica-Zdrój, d Ojców, e Czerna, f Białowieża

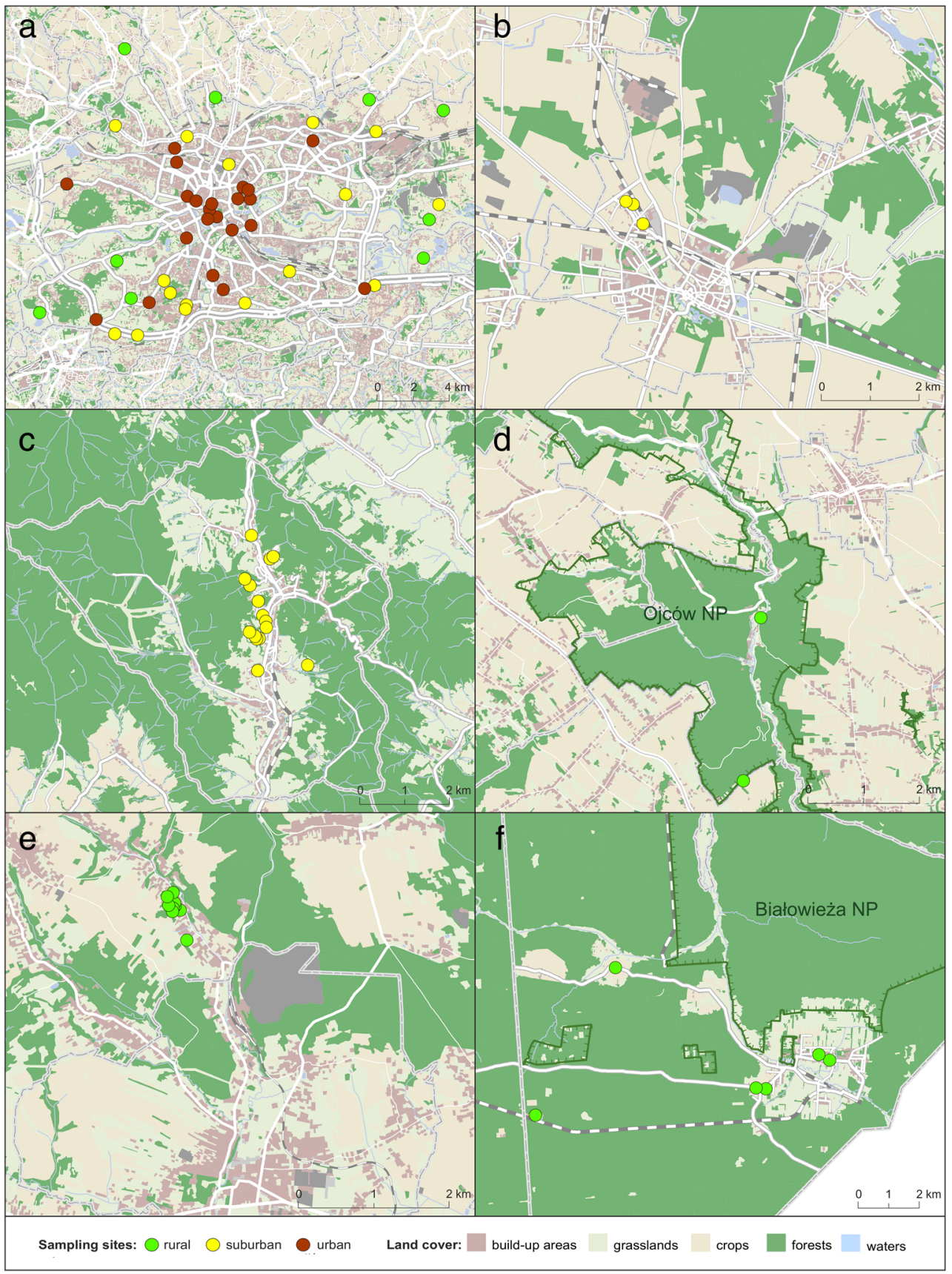


sites including six landscape parks and three Natura 2000 habitat sites along with five nature reserves located in the city. Fauna in Kraków is diverse with 226 birds, 42 mammals, and 17 herpetofauna species (Baścik and Degórska 2015).

Strzelce Opolskie $\left(50^{\circ} 30^{\prime} 38^{\prime \prime} \mathrm{N}, 18^{\circ} 18^{\prime} 02^{\prime \prime} \mathrm{E}\right)$ is a small town in the Silesian Upland. The whole town is inhabited by 18,312 residents (Statistics Poland 2018). According to our categorisation of land use we classified this study area as suburban (Fig. 2b). This area is composed mostly of detached houses and small gardens. It is surrounded by large agricultural fields that comprise $59 \%$ of land use in the municipality. Small areas of uncultivated wastelands are present mostly near roads. Forests, mainly coniferous cover $30 \%$ of the municipality land. There are no natural watercourses or lakes within the studied area. There are no forms of nature protection in the town. Vertebrate fauna is represented by 15 mammal and 102 bird species (Spałek 2007).

Krynica - Zdrój $\left(49^{\circ} 25^{\prime} 17^{\prime \prime} \mathrm{N}, 20^{\circ} 57^{\prime} 33^{\prime \prime} \mathrm{E}\right)$ is a small town situated in southern Poland in the Beskid Sadecki Mountains Range. The number of citizens is estimated to be around 11,165 (Statistics Poland 2018). The town, classified as suburban, is surrounded by coniferous and mixed forests, comprising $15 \%$ of the town as well as small patches of fields and meadows (Fig. 2c). Apart from a few blocks of flats, most of the settlements are detached houses. The town is a part of two habitat and one bird Natura 2000 sites and two landscape national parks. Vertebrate fauna is rich and characterised by numerous bird and mammal species (Kobiela et al. 2012).

Ojców National Park (ONP) $\left(50^{\circ} 12^{\prime} 46^{\prime \prime} \mathrm{N}, 19^{\circ} 49^{\prime} 56^{\prime \prime} \mathrm{E}\right)$ is situated in the Silesian Upland. With a total area of $21.46 \mathrm{~km}^{2}$ it is the smallest national park in Poland. The park consists mainly of two valleys. The vegetation is dominated by deciduous and mixed forests. These communities occupy $75 \%$ of the park. However, the diverse topography allows for occurrence of both xerothermic and mountain plant species (Partyka and Klasa 2008). The study site, the Ojców village, is located in the centre of ONP, defined in our research as rural (Fig. 2d). It has about 250 citizens (Statistics Poland 2018). The area of the park is also protected as a Natura 2000 habitat site. Vertebrate fauna is represented by 36 mammal and 120 bird species (Partyka and Klasa 2008).

Czerna $\left(50^{\circ} 10^{\prime} 14^{\prime \prime} \mathrm{N}, 19^{\circ} 37^{\prime} 22^{\prime \prime} \mathrm{E}\right)$ is a village with around 1200 residents and is located in the Olkusz Upland (Statistics Poland 2018). The village classified as rural comprises of mostly detached houses and farm buildings in close proximity to forest patches and fields (Fig. 2e). The forests constitute around $20 \%$ of the area. They are mostly deciduous and mixed forests. The village with its surrounding lands is protected as an important Natura 2000 habitat site as well as a landscape national park. Species richness of vertebrate fauna is similar as in ONP (Kotuła 2013).

Białowieża $\left(52^{\circ} 42^{\prime} 02^{\prime \prime} \mathrm{N}, 23^{\circ} 52^{\prime} 03^{\prime \prime} \mathrm{E}\right)$ is a village in northeastern Poland near the border with Belarus, inhabited by
2687 residents (Statistics Poland 2018). It is situated in the Bielsk Plain in close proximity of Białowieża National Park (BNP). The village, classified as rural, includes mainly detached houses and farm buildings. It is located at a glade of about $13 \mathrm{~km}^{2}$ within the central part of the Białowieża Primeval Forest (BPF), with the distance to the forest border not larger than $1 \mathrm{~km}$ (Fig. 2f). The village is situated within the Natura 2000 habitat site and a landscape national park. The BPF is a unique example of the best preserved European lowland forest, which experienced very little human interference during the last few centuries. The whole area is known for its high biodiversity of plants and animals. There are 153 bird and 60 mammal species (Kujawa et al. 2016).

\section{Diet analysis}

We studied the diet of cats based on scats and stomach analysis. We collected scats in all study sites except of the Kraków study site due to problems with finding suitable places for litterboxes. This was due to high disturbance of litterboxes by residents and pets, mainly dogs, in this area. Therefore, in Kraków, we based diet analysis only on stomach content obtained from road-killed cats that had been collected by the "Wild Rescue" company ('Dzikie Pogotowie Maciej Lesiak') with the permission of the local municipality. The animals were assigned to the urban, suburban, or rural category based on the place where they were found. We based that assumption on the fact that mean home ranges of cats in residential areas are usually smaller than 2 ha (Thomas et al. 2014). We assumed that there are no truly feral cats in Krakow (i.e. cats not relying on anthropogenic resources), rather stray cats or free-ranging pet cats. In order to collect scats, we asked resident cat owners to voluntarily participate in our study. With their permission, we placed litterboxes filled with sand in the neighbourhood of their house or near farm buildings to collect scats deposited by cats. We also searched other places in the vicinity that would be attractive for cats like sand pits and flower beds. Scats were collected usually in 2 weeks intervals.

Both the scats and road-killed cats were assigned to urbanisation level and season, transported to the laboratory and kept in a freezer for several days. Scats and stomach contents were soaked in water with detergent for 1-2 days. Next, the material was washed on sieves to separate the food remains, which were afterwards dried at $60{ }^{\circ} \mathrm{C}$ for $24 \mathrm{~h}$ (Jędrzejewska and Jędrzejewski 1998). The dried material was divided into main food categories: mammals (bones and hair), birds (bones and feathers), insects (exoskeletons), plant material (fruits, seed and leaves), anthropogenic material (food and trash).

Prey remains were identified using keys and reference material stored as a collection belonging to the Institute of Environmental Sciences Jagiellonian University. Mammals were identified to species or genus based on bones and teeth 
(Pucek 1984) and hair (Teerink 2003). Birds were identified to the order based on feathers (Dove and Koch 2011). Anthropogenic food included both dry and/or canned cat food, as well as remains of human food such as sausages, chicken or potatoes. Plant material, though commonly present in scats and stomachs, was not considered as a food category as it was most probably eaten by accident with other food (e.g., pieces of dead leaves) or to help clean their digestive tract (grass) and we excluded this category from further calculations.

\section{Prey brought home analysis}

Cat owners were asked to collect or take pictures of dead animals brought home by their cats. In addition, we searched for prey remains in proximity to litterboxes during regular control monitoring. Cats' prey were collected in suburban (Krynica - Zdrój, Strzelce Opolskie) and rural areas (Czerna, Białowieża). Due to the same problems as with scats, we did not collect cat prey in Kraków. Prey species were identified from photos taken by cat owners or by direct examination of collected prey individuals. For further analysis prey were divided into six categories: rodents, soricomorphs, other mammals (such as lagomorphs and carnivorans), birds, reptiles, and invertebrates. We did not, however, include invertebrate prey in the statistical analysis of prey, as only one case was reported during our study (Online Resource 2.).

\section{Statistical analysis}

For the purpose of data analysis, we divided food material from scats and stomachs into five categories: rodents, soricomorphs, birds, insects, and anthropogenic food. We calculated the frequency of occurrence of each food category $(\% \mathrm{FO})$ which is the percentage of scat and stomach samples containing a food category. Frequencies of different food categories (i.e. in both scats and stomach samples) in relation to study site, urbanisation level and season were compared by $\chi^{2}$ test, with $p \leq 0.05$ considered significant.

We calculated the monthly individual predation rate (MPR) on vertebrate prey, separately for different urbanisation categories as:

$\mathrm{MPR}=\frac{\mathrm{N} \text { vertebrate prey items }}{\mathrm{N} \text { samples }} \times 30$ days;

based on the assumption that one scat represents food consumed during the prior $24 \mathrm{~h}$ (Krauze-Gryz et al. 2012). For the sake of comparison, we applied this assumption for stomach samples too, although we are aware that there can be a bias resulting from differences in decomposition time between food items. MPR was calculated only for vertebrate prey as our methodology did not allow proper evaluation of number of individual invertebrates consumed. We compared predation rates between urban, suburban and rural habitats by using $\chi^{2}$ test. In order to check the potential bias resulting from including stomach samples into the analysis, we also calculated MPR for stomachs and scats separately.

Similar to the diet analysis, we compared the frequencies of five prey categories (rodents, soricomorphs, other mammals, birds, and reptiles) in relation to study site, urbanisation level, and season by $\chi^{2}$ test. For comparison of prey body mass, we used both mean body mass of collected prey individuals of certain species (we excluded prey items that were partially eaten). Based on literature data (Pucek 1984; Juszczyk 1987; Dunning 2007) we classified prey species into three body mass categories. The small size category $(<20 \mathrm{~g})$ included Sorex spp. and small passerines. The medium size category $(20-40 \mathrm{~g})$ included the most common species of rodents (e.g. Apodemus spp. Microtus spp.) and sparrow-size birds. The large size category ( $>40 \mathrm{~g}$ ) included larger species of mammals, birds and reptiles. The frequencies of cat predation on prey of different body mass category were compared by $\chi^{2}$ test.

We calculated trophic niche breadth indices, B (Levins' index) as follows:

$\mathrm{B}=\frac{1}{\sum \mathrm{pi} 2}$

where $B$ is the value of Levins' index, $p_{i}$ is percentage occurrence of $i$ food category, and standardised index $\mathrm{B}_{\mathrm{A}}$, calculated as follows:

$(\mathrm{BA}=) \frac{\mathrm{B}-1}{\mathrm{~N}-1} ;$

where $\mathrm{N}$ is the number of food categories, both for diet and prey of the cats (Krebs 1989).

Both indices were calculated for a total number of samples in diet and prey analysis as well as separately in relation to urbanisation level and season. We compared the indices values using U Mann-Whitney test with significance set at $p<0.05$. Statistical calculations were performed in Statistica Statsoft ver. 12).

\section{Results}

\section{Diet analysis}

We collected a total of 81 cat stomachs and 409 cat scats (Table 2). A total of 35 stomach samples were collected in the urban area, 23 in the suburban areas, and 23 in rural areas. 
Table 2 Total number of samples collected $(\mathrm{N})$ for diet and prey analysis, sample type and study site

\begin{tabular}{llllr}
\hline Type of collected material & Study site & Time of collection & Habitat & N \\
\hline Stomachs & Kraków & $2011-2013$ & Urban & 35 \\
& & & Suburban & 23 \\
& & & Rural & 23 \\
Scats & Krynica - Zdrój & $2012-2013$ & Suburban & 181 \\
& Białowieża & 2003 & Rural & 44 \\
& Czerna & $2012-2013$ & Rural & 75 \\
Prey brought home & Ojców NP & 2008 & Rural & 109 \\
& Strzelce Opolskie & $2014-2015$ & Suburban & 27 \\
& Krynica - Zdrój & $2012-2014$ & Suburban & 162 \\
& Białowieża & 2003 & Rural & 126 \\
& Czerna & $2012-2013$ & Rural & 22 \\
\hline
\end{tabular}

Scats were collected only in the suburban $(n=181)$ and rural $(n=228)$ areas. The largest number of samples were found in summer (31 stomachs, 175 scats) and the smallest in winter (9 stomachs, 38 scats). We identified a total number of 582 food items (excluding plant material). Remains of vertebrates were present in 252 scat and 20 stomach samples. Rodents were the most frequently observed prey (present in $38.4 \%$ of all samples; Fig. 3).

We found a significant difference in consumption of rodents in relation to the habitat type, based on both scats and stomach samples. The consumption was higher in the suburban and rural areas compared to the urban habitat $\left(\chi^{2}=8.86, \mathrm{df}=2, p=0.012\right.$; Fig. 4). We found no difference in consumption of rodents in relation to season. We identified 8 species of rodents, with the common vole (Microtus arvalis) as the most frequently eaten (Online Resource 2). Soricomorphs were consumed less frequently, being present in less than $6.7 \%$ of all samples. Soricomorphs were significantly more frequently consumed in suburban habitats compared to rural and urban (Yates corrected $\chi^{2}=12.677, \mathrm{df}=2, p=0.002$ ). We identified 5 soricomorph species, in which the Sorex spp. shrews were dominant (Online Resource 2). Bird remains were found in $13.7 \%$ of collected stomachs and scats, with the highest observation rate in winter when $23.4 \%$ of samples contained this prey category $\left(\chi^{2}=11.23, \mathrm{df}=3, p=0.011\right.$; Fig. 3$)$. There was no variation between habitat types in terms of bird consumption. Amongst birds, four items were identified as Columbiformes remains, others with the rest either being Passeriformes or unidentified birds. Invertebrates (insects and spiders) were present in $22.7 \%$ of samples and were consumed more often in summer and autumn than in winter and spring $\left(\chi^{2}=20.68, \mathrm{df}=3, p=0.0001\right)$. Various anthropogenic food was present in $34.9 \%$ of samples. The consumption of anthropogenic food varied between both season and habitat types. Cats ate significantly more anthropogenic food in urban habitats $\left(\chi^{2}=12.91, \mathrm{df}=2, p=0.0002\right)$ and seasons other than summer $\left(\chi^{2}=9.87, \mathrm{df}=3, p=0.02\right)$. The plant material (mostly grass) was found in $57.8 \%$ of scat and stomach samples.

We found significant differences in prey consumption between study sites $\left(\chi^{2}=35.92, \mathrm{df}=4, p<0.0001\right)$ as $79 \%$ of scats collected in Ojców NP and 70\% collected in Białowieża contained remains of vertebrates, which is higher than average in our study ( $54 \%$ of all stomach and scat samples contained vertebrate remains). In contrast, only $17 \%$ of stomachs collected in Kraków urban area contained vertebrate prey $(25 \%$ from all habitat types in Kraków study site). Rodents were the most frequently consumed prey category in all study sites. However, their frequencies were higher than expected in
Fig. 3 Food categories of domestic cats based on diet analysis in relation to season. $\% \mathrm{FO}$ is the (frequency of samples containing food category)/(total number of samples) $\times 100 \%$. Letters above bars indicate statistical difference based on $\chi^{2}$ test

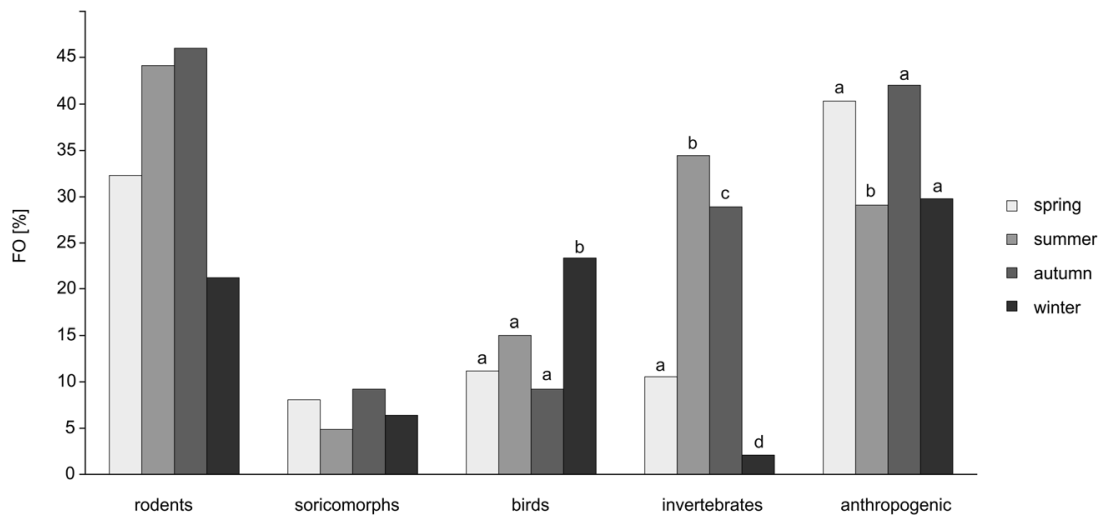


Fig. 4 Food categories of domestic cats based on diet analysis in relation to habitat type. $\% \mathrm{FO}$ - frequency of samples containing food category / total number of samples $\times 100$. Letters above bars indicate statistical difference based on $\chi^{2}$ test

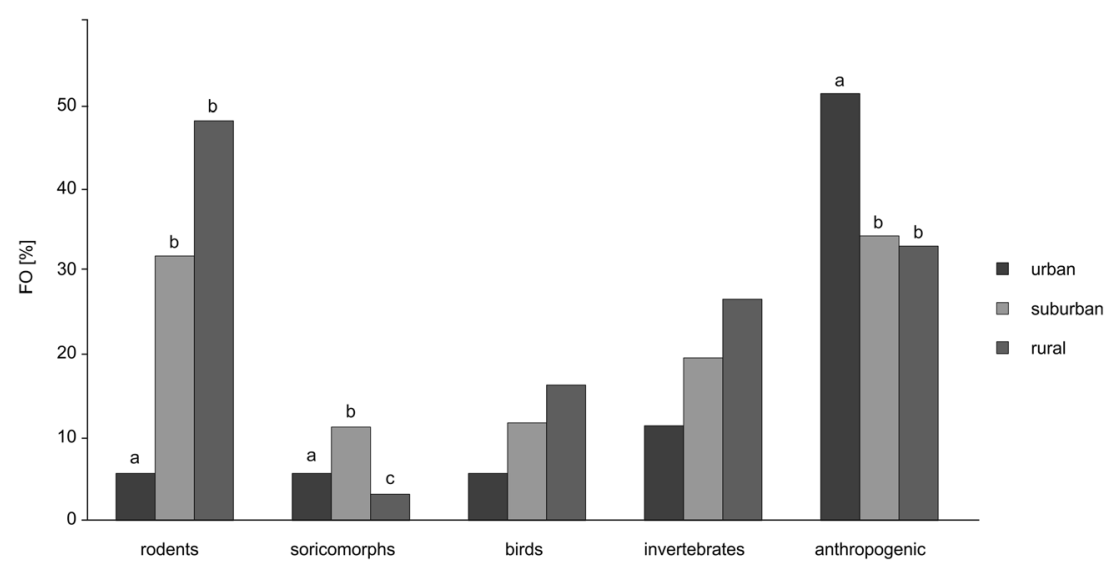

Ojców and Białowieża $(\chi 2=20.01, \mathrm{df}=4, p=0.0005)$. Birds were consumed as frequently as rodents by cats in Białowieża, while in other study sites their proportion in the diet was significantly lower $\left(\chi^{2}=24.05, \mathrm{df}=4, p<0.0001\right)$. The anthropogenic food was most frequently observed in Kraków study site $\left(\chi^{2}=37.25, \mathrm{df}=4, p<0.0001\right)$ and almost absent from the samples from Białowieża. The predation rates differed among habitats $\left(\chi^{2}=18.27, \mathrm{df}=2, p=0.0001\right)$. MPR was lowest in urban areas (MPR $=5.14)$ and higher in suburban $(M P R=16.62)$ and rural areas $(M P R=22.11)$. This trend remained after dividing stomachs and scats into separate categories. The MPR values for stomachs were lower (suburban $\mathrm{MPR}=6.52$, rural $\mathrm{MPR}=15.65$ ) than for scats (suburban $\mathrm{MPR}=17.24$, rural MPR $=22.76$ ).

\section{Prey brought home analysis}

We collected 337 prey items from cats living in suburban $(n=$ $189)$ and rural areas $(n=148)$ (Tab. 2). We identified 51 prey species and grouped them into six categories (rodents, soricomorphs, other mammals, birds, reptiles and invertebrates). Rodents were the most numerous prey (58\% of all prey individuals; Online Resource 2.). We found no significant difference in the number of depredated rodents between the seasons (Fig. 5). Rodents were more frequently killed by cats in suburban compared to rural habitats $\left(\chi^{2}=7.71, \mathrm{df}=1\right.$, $p=0.005$; Fig. 6). Among 11 identified species, bank vole (Myodes glareolus) and Apodemus spp. mice were the dominant prey species killed and brought home by cats in suburban and rural habitats respectively (Online Resource 2). Soricomorphs constituted for $14 \%$ of collected prey individuals. In suburban habitats we identified 4 species with lesser white-toothed shrew (Crocidura suaveolens) being the most common prey, whereas in rural areas we identified 3 species, with the European mole (Talpa europaea) and common shrew being most frequent. Soricomorphs were less often found in prey brought home in suburban areas $\left(\chi^{2}=4.68, \mathrm{df}=1, p=\right.$ $0.031)$. The same prey group was also less common in spring compared to other seasons $\left(\chi^{2}=10.02, \mathrm{df}=3, p=0.018\right)$.
Mammals other than rodents and soricomorphs were killed by cats sporadically ( 5 prey items, $1.5 \%$ of all prey individuals). We found two individuals of the least weasel (Mustela nivalis) killed by cats in suburban areas and single prey cases of the stoat (Mustela erminea), European hare (Lepus europaeus), and brown long-eared bat (Plecotus auritus) found in rural areas (Online Resource 2). Although birds constituted only $23 \%$ of prey items brought home, this category was the most diverse and included 27 species. Various Passeriformes species were most commonly killed by the cats, (e.g. Passer domesticus, Locustella naevia, Turdus merula) and there was no one dominant bird species brought home by cats (Online Resource 2). One case of depredation on a young chicken (Gallus Gallus domesticus) was recorded. We found no significant difference in bird depredation between seasons or habitats. Reptiles comprised $4 \%$ of all prey items (12 individuals). We identified four species, three lizard species and one snake, respectively. Almost all reptiles were killed by the cats in summer and only one snake (Natrix natrix) in autumn. We found one case of an invertebrate prey brought home by a cat, i.e. a southern hawke (Aeshna cyanea).

There were no significant differences in proportion of prey categories between study sites except for rodents, which were more likely to be brought home by cats in Krynica-Zdrój than other sites $\left(\chi^{2}=9.68, \mathrm{df}=3, p=0.021\right)$. With respect to body size of the prey, the dominant body mass category was medium-sized, followed by the small and then large body mass categories, with proportions of $70.3 \%, 17.8 \%$, and $11.9 \%$, respectively $\left(\chi^{2}=209.31, \mathrm{df}=2 p<0.001\right)$. This trend was present in all seasons and both habitat types.

\section{Trophic niche breadth and proportions of food categories}

The trophic niche breadth indices calculated on diet analysis were higher than those based on prey analysis $(\mathrm{U}=0.00, p=$ $0.03)$. The niche breadth was the broadest in summer both for diet and prey analysis (Table 3 ). However, there was a difference in relation to habitat type. Based on diet analysis, the 
Fig. 5 Prey categories of domestic cats based on prey brought home analysis in relation to season. Letters above bars indicate statistical difference based on $\chi^{2}$ test

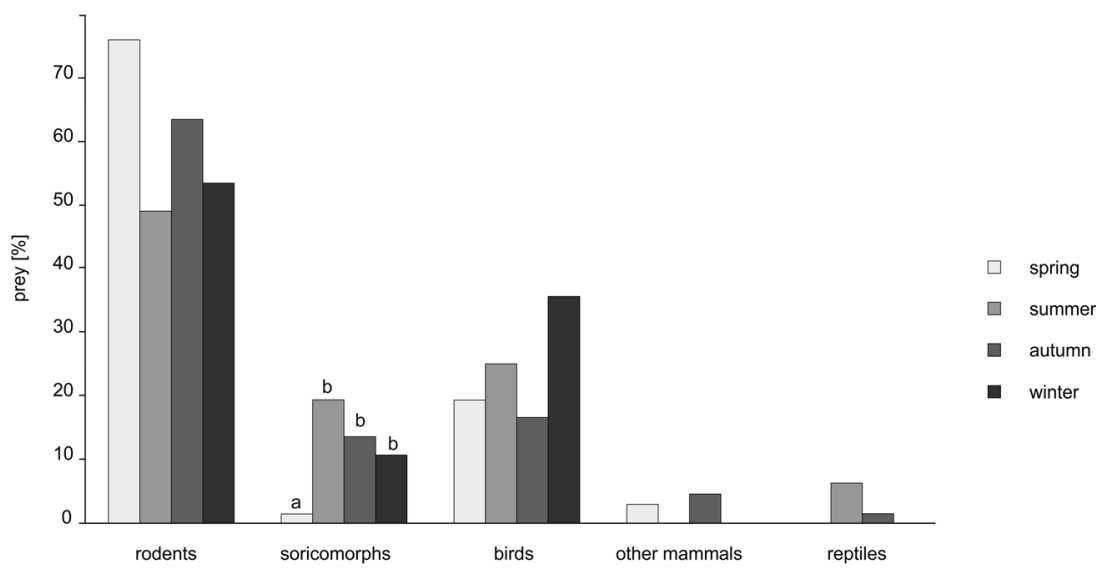

niche breadth was broadest in suburban areas $(B=4.17)$, whereas based on prey analysis, the trophic niche breadth of cats in rural areas was broader than in the suburban areas $(B=$ 3.01 and $\mathrm{B}=1.92$, respectively).

\section{Discussion}

Our study showed significant differences in prey consumption by domestic cats in relation to the level of urbanisation. The individual predation rate was the lowest in urban areas as compared to the rural cats, and there was a significant difference in predation on rodents and soricomorphs. The results may thus suggest that the most substantial effect of cats predation on wildlife can be expected for those populations living close to protected areas often harbouring unique species of wildlife. Although our sample size from urban area was small and came from only one study site, we believe, this result is reliable, because similar findings were reported by other studies. For instance, Gillies and Clout (2003) showed that cats tend to kill fewer rodents in urbanised areas, whereas Brickner-Braun et al. 2007) found even no animal prey remains in 43 cat stomachs. However, it should be noted that even if the individual predation rate of urban cats may be low, there are likely to be a greater number, and hence density, of cats in urban than rural areas (Lepczyk et al. 2004; Baker et al. 2005) and that the total predation of all cats in certain areas may still have a large impact on wildlife.

In our study, the main prey of cats was consistent with other studies conducted in temperate climates with rodents being the dominant prey category, followed by birds and soricomorphs (Weber and Dailly 1998; Kays and DeWan 2004; Tschanz et al. 2011). Voles were the most frequently eaten rodents, whereas mice were more commonly brought home, and this trend has been previously reported (KrauzeGryz et al. 2012). For prey brought home, we found that rural cats brought more soricomorphs, but fewer rodents home than suburban cats.

In the Kraków study site we observed both high frequency of anthropogenic food and low frequency of prey in the cats' diet. Thus, the high availability of anthropogenic food found in urban areas may be the reason for less prey found. However, we did not assess prey abundance, so direct comparison of environmental availability relative to consumption cannot be made. The free-ranging cats from urban areas are often fed intentionally by residents and have easy access to human food waste (Levy et al. 2003). On the other hand, historically, in Poland as in other European countries, cats in
Fig. 6 Prey categories of domestic cats based on prey brought home analysis in relation to habitat type. Letters above bars indicate statistical difference based on $\chi^{2}$ test

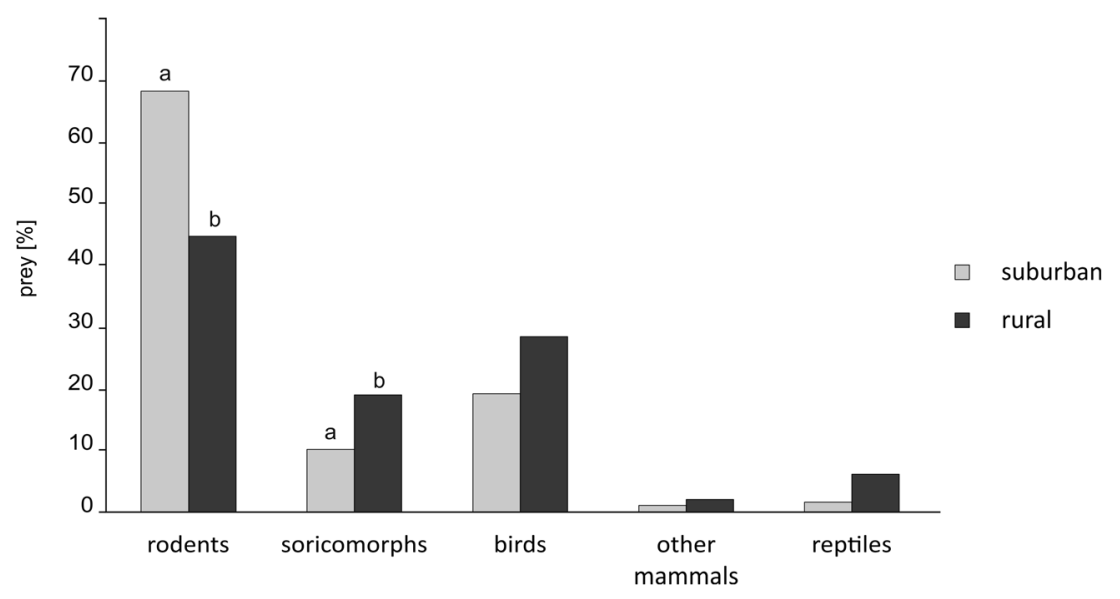


Table 3 Trophic niche breadth estimations based on diet and prey analysis in relation to season and habitat type

\begin{tabular}{lll}
\hline & $\mathrm{B}$ & $\mathrm{B}_{\mathrm{A}}$ \\
\hline Diet analysis & & \\
Total & 3.94 & 0.73 \\
Winter & 3.56 & 0.64 \\
Spring & 3.53 & 0.63 \\
Summer & 3.85 & 0.71 \\
Autumn & 3.75 & 0.69 \\
Urban & 2.23 & 0.31 \\
Suburban & 4.17 & 0.79 \\
Rural & 3.69 & 0.67 \\
Prey analysis & & \\
Total & 2.38 & 0.46 \\
Winter & 2.35 & 0.34 \\
Spring & 1.52 & 0.13 \\
Summer & 2.89 & 0.47 \\
Autumn & 2.02 & 0.25 \\
Suburban & 1.92 & 0.23 \\
Rural & 3.01 & 0.50 \\
\hline$B$ Levis & &
\end{tabular}

$B$ Levin's index, $B_{A}$ standardised Levin's index

rural areas were traditionally poorly fed, so they could become better rodent hunters. This attitude, however, has slowly changed and nowadays, both cats in rural and suburban areas tend to benefit more from anthropogenic food (Weber and Dailly 1998).

Despite of potential seasonal changes in availability of prey, in our study, the consumption of some prey categories did not vary significantly between seasons. For example rodents were consumed at a similar rate throughout the seasons, even though they are more abundant in summer and autumn (Pucek et al. 1993). Birds were killed more often during winter, which may be due to artificial feeding by people using bird feeders at this time of year (Dunn and Tessaglia 1994). This higher number of birds killed in winter differs from other studies, which found more birds killed by cats from spring to early autumn (Baker et al. 2005; Loyd et al. 2017; Mcruer et al. 2017).

Using direct (prey brought home) and indirect (scats and stomach analysis) methods to analyse cat predation we are able to illustrate the advantages and disadvantages of both methods. Although the prey brought home method is widely used for estimating cat predation rate (Woods et al. 2003; Lepczyk et al. 2004; Baker et al. 2008; Tschanz et al. 2011; Krauze-Gryz et al. 2017), we believe that this method alone is inadequate to be used alone. First of all, in our study, the differences in proportions of prey categories were much less visible based on prey brought home than on diet analysis. In all study sites, we observed high variation of this particular behaviour between cats as some cats brought home a variety of prey regularly while other did not, which is consistent with other studies (Robertson 1998; Tschanz et al. 2011; Wood et al. 2016). This variability and the lack of witnessing all depredation events causes the underestimation of actual predation rate of studied cats. For instance, in contrast to the study by KrauzeGryz et al. (2017) based entirely on prey taken home, we revealed higher predation rates on birds in rural areas, especially in the Białowieża study site where rodents and birds were consumed at the same frequencies. Moreover, because the prey brought home method requires the cooperation of cat owners to collect and identify the prey it may also introduce problems related to species identification, particularly the misidentification of rare species as common ones. Furthermore, owners may underestimate cases of predation in fear of being accused of their cats causing harm to wildlife or knowing that cats killing wildlife is an environmental problem (Coleman and Temple 1993; Lepczyk et al. 2004; Baker et al. 2008). In contrast, the diet analysis is likely a better method for estimating predation rate because scat content covers all food items consumed during a $24 \mathrm{~h}$ period and there is less possibility of personal bias. The monthly predation rates in our study are greater than those estimated from prey brought home analysis in other studies (Kays and DeWan 2004; Tschanz et al. 2011). However, the number of detected prey species was lower in diet analysis than in prey analysis. In the case of birds, one reason is that we were unable to distinguish various species of small birds from the bones and feathers present in cat scats. Mammals, on the other hand, were easier to identify by teeth and fur remains. Nonetheless, the number of detected species was smaller in diet analysis (14 species) than prey analysis ( 20 species). While analysis of scats and stomachs did not show any reptiles being eaten by cats, we found 12 individuals of four species among collected prey. These differences may reflect a potential bias between analysing scats and stomachs samples. Food remains were easier to identify in stomach samples, as they were less decomposed. Interestingly, in our study the MPR values calculated from stomachs were lower than those from scats, further supporting our hypothesis that cats from more urbanised areas have lower MPR. We suggest that combining all methods can be beneficial and allow for better estimates of both predation rate and prey diversity and, consequently, the true effect of the domestic cat on wildlife. Nevertheless, there are some aspects of cat impact on wildlife that will still be missed. Animals attacked by cats are often left dead or injured in the field (Loyd et al. 2017). As this prey is neither eaten nor brought to the household it will be undetected by diet or prey analysis, which, therefore, leads to underestimation of cat impact on wildlife. A study using video cameras attached to cats showed that $49 \%$ of prey killed by the free-ranging cats 
was left in the field, while $28 \%$ and $23 \%$ of prey was eaten or brought home, respectively (Loyd et al. 2013). As a result, our findings are almost certainly underestimated.

Our study shows that free ranging cats living in close proximity to natural habitats had a greater diversity of prey species than those living in more densely populated areas. This difference is likely a result of a greater diversity of prey availability in these natural habitats, though we did not explicitly evaluate it. Although we did not evaluate prey abundance, our findings do indicate that it would be beneficial for nature conservationists to introduce some means of cat population control in areas with a high conservation value. Furthermore, keeping cats indoors is the most effective option to reduce predation. As an alternative for letting cats roam freely, walking cats on a leash and providing them with enclosures (catios) should be promoted. Because cat owners in Poland still oppose the idea of constant indoor confinement of their pets (Sidhu et al. 2017; Walker et al. 2017) we believe that education and broader access to the results of studies on cat outdoor activity is necessary to encourage people to become more responsible cat owners. Education programs should not only focus on cat predation but also the risks the free-ranging cats encounter while roaming, e.g. infection with parasites (Chalkowski et al. 2019) and vehicle accidents (Rochlitz 2003). This effort should be made especially towards cat owners living in close proximity of areas of high conservation value. Furthermore, changing policies that promote responsible pet ownership are an important part of the solution.

Acknowledgements This project was partially sponsored by Jagiellonian University (grant N18/DBS/000003). We want to thank Edyta Besztocha, Monika Łudzik and Adam Andrzej Panfiluk for their help with sample collection and Aleksandra Szypowska for proofreading of our manuscript. We thank the reviewers and associate editor for their valuable comments and suggestions that allowed us to greatly improve the first version of this manuscript.

\section{Compliance with ethical standards}

Conflict of interest The authors declare that they have no conflict of interest.

Ethical standards The collection of the material and analyses within the research submitted to Urban Ecosystems was conducted in line with the current legislative regulations obligatory in Poland that do not require additional ethical clearance.

Open Access This article is licensed under a Creative Commons Attribution 4.0 International License, which permits use, sharing, adaptation, distribution and reproduction in any medium or format, as long as you give appropriate credit to the original author(s) and the source, provide a link to the Creative Commons licence, and indicate if changes were made. The images or other third party material in this article are included in the article's Creative Commons licence, unless indicated otherwise in a credit line to the material. If material is not included in the article's Creative Commons licence and your intended use is not permitted by statutory regulation or exceeds the permitted use, you will need to obtain permission directly from the copyright holder. To view a copy of this licence, visit http://creativecommons.org/licenses/by/4.0/.

\section{References}

Álvarez-Castañeda ST, Ortega-Rubio A (2003) Current status of rodents on islands in the Gulf of California. Biol Conserv 109(2):157-163

Baker PJ, Bentley AJ, Ansell RJ, Harris S (2005) Impact of predation by domestic cats Felis catus in an urban area. Mammal Rev 35(3-4): 302-312

Baker PJ, Molony SE, Stone E, Cuthill IC, Harris S (2008) Cats about town: is predation by free-ranging pet cats Felis catus likely to affect urban bird populations? Ibis 150(s1):86-99

Baścik M, Degórska B (2015) Natural environment of Krakow. Institute of Geography and Spatial Management, Jagiellonian University, Kraków

Bonnaud E, Medina FM, Vidal E, Nogales M, Tershy B, Zavaleta E, Donlan CJ, Keitt B, le Corre M, Horwath SV (2011) The diet of feral cats on islands: a review and a call for more studies. Biol Invasions 13(3):581-603

Brickner-Braun I, Geffen E, Yom-Tov Y (2007) The domestic cat as a predator of Israeli wildlife. Israel J Ecol Evol 53(2):129-142

Chalkowski K, Wilson AE, Lepczyk CA, Zohdy S (2019) Who let the cats out? A global meta-analysis on risk of parasitic infection in indoor versus outdoor domestic cats (Felis catus). Biol Lett 15(4): 20180840

Coleman JS, Temple SA (1993) Rural residents' free-ranging domestic cats: a survey. Wildl Soc Bull 21:381-390

Dickman CR, Newsome TM (2015) Individual hunting behaviour and prey specialisation in the house cat Felis catus: implications for conservation and management. Appl Anim Behav Sci 173:76-87

Doherty TS, Glen AS, Nimmo DG, Ritchie EG, Dickman CR (2016) Invasive predators and global biodiversity loss. Proc Natl Acad Sci U S A 113(40):11261-11265. https://doi.org/10.1073/pnas. 1602480113

Dove CJ, Koch SL (2011) Microscopy of feathers: a practical guide for forensic feather identification. Microscope-Chicago 59(2):51

Dowding JE, Murphy EC (2001) The impact of predation by introduced mammals on endemic shorebirds in New Zealand: a conservation perspective. Biol Conserv 99(1):47-64

Duany A, Talen E (2002) Making the good easy: the smart code alternative. Fordham Urban Law J 29:1445

Dunn EH, Tessaglia DL (1994) Predation of birds at feeders in winter (Depredación de Aves en Comederos Durante el Invierno). J Field Ornithol:8-16

Dunning JB Jr. (2007). Handbook of avian body masses, 2nd edn. CRC Press, Boca Raton

Farnworth MJ, Campbell J, Adams NJ (2011) What's in a name? Perceptions of stray and feral cat welfare and control in Aotearoa, New Zealand. J Appl Anim Welf Sci 14(1):59-74

Faulquier L, Fontaine R, Vidal E, Salamolard M, Le Corre M (2009) Feral cats Felis catus threaten the endangered endemic Barau's petrel Pterodroma baraui at Reunion Island (Western Indian Ocean). Waterbirds 32:330-336

FEDIAF Facts \& figures (2016). http://www.fediaf.org/52-dcs-statistics (accessed 15 December 2017)

Flockhart DTT, Norris DR, Coe JB (2016) Predicting free-roaming cat population densities in urban areas. Anim Conserv 19(5):472-483

Gajda A, Pancewicz $\longleftarrow$ (2018) Application of the big-data approach to create a country-wide, GIS-based monitoring system of functional zones and urban compactness based on land use/land cover analysis in Poland, A world of flows: labour mobility, capital and knowledge in an age of global reversal and regional revival. Università della Svizzera Italiana Lugano, Switzerland, p 64

Gillies C, Clout M (2003) The prey of domestic cats (Felis catus) in two suburbs of Auckland City, New Zealand. J Zool 259(3):309-315 
Jędrzejewska B, Jędrzejewski W (1998) Predation in vertebrate communities: the Bialowieza primeval forest as a case study. SpringerVerlag, Berlin

Juszczyk W (1987). Plazy i gady krajowe [Amphibians and reptiles of Poland]. Panstwowe Wydawnictwo Naukowe, Warszawa, Poland

Kays RW, DeWan AA (2004) Ecological impact of inside/outside house cats around a suburban nature preserve. Anim Conserv 7(3):273283

Kobiela K, Moczulski M, Polus M, Zarzycki J (2012). Prognoza oddziaływania na środowisko projektu programu ochrony środowiska dla gminy Krynica Zdrój na lata 2012-2015 z perspektywą do roku 2019 [Environmental impact assessment to environmental protection program for Krynica Zdrój municipality for years 2012-2015 with perspective for year 2019]. Krynica Zdrój

Kotuła $Ł$ (2013) Prognoza oddziaływania na środowisko do projektu miejscowego planu zagospodarowania przestrzennego miasta Krzeszowice [Environmental impact assessment to local spatial management plan for Krzeszowice city]. Instytut Rozwoju Miast, Kraków

Krauze-Gryz D, Gryz J, Goszczyński J (2012) Predation by domestic cats in rural areas of Central Poland: an assessment based on two methods. J Zool 288(4):260-266

Krauze-Gryz D, Żmihorski M, Gryz J (2017) Annual variation in prey composition of domestic cats in rural and urban environment. Urban Ecosyst 20(4):945-952

Krebs CJ (1989) Ecological methodology. Harper \& Row, New York

Kujawa A, Orczewska A, Falkowski M, Blicharska M, Bohdan A, Buchholz L et al (2016) The Białowieża forest - a UNESCO natural heritage site - protection priorities. For Res Pap 77(4):302-323

Lepczyk CA, Mertig AG, Liu J (2004) Landowners and cat predation across rural-to-urban landscapes. Biol Conserv 115:191-201. https://doi.org/10.1016/S0006-3207(03)00107-1

Lepczyk CA, Lohr CA, Duffy DC (2015) A review of cat behavior in relation to disease risk and management options. Appl Anim Behav Sci 173:29-39

Lepczyk CA, Duffy DC (2018) Feral cats. In: Pitt WC, Beasley JC, Witmer GW (eds) Ecology and management of terrestrial vertebrate invasive species in the United States. CRC, Boca Raton, pp 269-310

Levy JK, Gale DW, Gale LA (2003) Evaluation of the effect of a longterm trap-neuter-return and adoption program on a free-roaming cat population. J Am Vet Med Assoc 222(1):42-46

Loss S, Will T, Marra P (2013) The impact of free-ranging domestic cats on wildlife of the United States. Nat Commun 4:1396. https://doi. org $/ 10.1038 /$ ncomms 2380

Loss SR, Marra PP (2017) Population impacts of free-ranging domestic cats on mainland vertebrates. Front Ecol Environ 15(9):502-509. https://doi.org/10.1002/fee.1633

Loyd KAT, Hernandez SM, Carroll JP, Abernathy KJ, Marshall GJ (2013) Quantifying free-roaming domestic cat predation using animal-borne video cameras. Biol Conserv 160:183-189

Loyd KAT, Hernandez SM, McRuer DL (2017) The role of domestic cats in the admission of injured wildlife at rehabilitation and rescue centers. Wildl Soc Bull 41(1):55-61

Mcruer DL, Gray LC, Horne LA, Clark EE Jr (2017) Free-roaming cat interactions with wildlife admitted to a wildlife hospital. J Wildl Manag 81(1):163-173

Medina FM, Nogales M (2009) A review on the impacts of feral cats (Felis silvestris catus) in the Canary Islands: implications for the conservation of its endangered fauna. Biodivers Conserv 18(4):829-846

Medina FM, Bonnaud E, Vidal E, Tershy BR, Zavaleta ES, Josh Donlan C, Keitt BS, Corre M, Horwath SV, Nogales M (2011) A global review of the impacts of invasive cats on island endangered vertebrates. Glob Chang Biol 17(11):3503-3510

Metsers EM, Seddon PJ, van Heezik YM (2010) Cat-exclusion zones in rural and urban-fringe landscapes: how large would they have to be? Wildl Res 37(1):47-56

Moseby KE, Peacock DE, Read JL (2015) Catastrophic cat predation: a call for predator profiling in wildlife protection programs. Biol Conserv 191:331-340

Nelson SH, Evans AD, Bradbury RB (2005) The efficacy of collarmounted devices in reducing the rate of predation of wildlife by domestic cats. Appl Anim Behav Sci 94(3-4):273-285

Partyka J, Klasa A (2008) Monografia Ojcowskiego Parku Narodowego. [Monograph of Ojców National Park]. Przyroda, Ojcowski Park Narodowy, Ojców

Pucek Z (1984) Klucz do oznaczania ssaków Polski [Key for identification of polish mammals]. Państwowe Wydawnictwo Naukowe, Warszawa

Pucek Z, Jędrzejewski W, Jędrzejewska B, Pucek M (1993) Rodent population dynamics in a primeval deciduous forest (Białowieża National Park) in relation to weather, seed crop, and predation. Acta Theriol 38(2):199-232

Risbey DA, Calver MC, Short J (1999) The impact of cats and foxes on the small vertebrate fauna of Heirisson prong, Western Australia. I Exploring potential impact using diet analysis. Wildl Res 26(5):621-630

Robertson ID (1998) Survey of predation by domestic cats. Aust Vet J 76(8):551-554

Rochlitz I (2003) Study of factors that may predispose domestic cats to road traffic accidents: part 1. Vet Rec 153(18):549-553

Sidhu, R., Gunawan, E., \& Ishikawa, R. (2017). A sky without birds: perceptions of cat predation in British Columbia

Spałek K (2007) Inwentaryzacja i waloryzacja przyrodnicza gminy Strzelce Opolskie [Wildlife conservation evaluation of Strzelce Opolskie municipality]. Krasiejów

Statistics Poland (2018) https://stat.gov.pl (accessed 10 January 2018)

Széles GL, Purger JJ, Molnár T, Lanszki J (2018) Comparative analysis of the diet of feral and house cats and wildcat in Europe. Mammal Res 63(1):43-53

Teerink BJ (2003) Hair of west European mammals: atlas and identification key. Cambridge University Press, Cambridge

Thomas RL, Baker PJ, Fellowes MD (2014) Ranging characteristics of the domestic cat (Felis catus) in an urban environment. Urban Ecosyst 17(4):911-921

Tschanz B, Hegglin D, Gloor S, Bontadina F (2011) Hunters and nonhunters: skewed predation rate by domestic cats in a rural village. Eur J Wildl Res 57(3):597-602

van Heezik Y, Smyth A, Adams A, Gordon J (2010) Do domestic cats impose an unsustainable harvest on urban bird populations? Biol Conserv 143(1):121-130

Walker JK, Bruce SJ, Dale AR (2017) A survey of public opinion on cat (Felis catus) predation and the future direction of cat management in New Zealand. Animals 7(7):49

Weber JM, Dailly L (1998) Food habits and ranging behaviour of a group of farm cats (Felis catus) in a Swiss mountainous area. J Zool 245(2):234-237

Wierzbowska IA, Olko J, Hędrzak M, Crooks KR (2012) Free-ranging domestic cats reduce the effective protected area of a Polish national park. Mammal Biol 77(3):204-210

Wood V, Seddon PJ, Beaven B, van Heezik Y (2016) Movement and diet of domestic cats on Stewart Island/Rakiura, New Zealand. N Z J Ecol 40(1):186-190

Woods M, McDonald RA, Harris S (2003) Predation of wildlife by domestic cats Felis catus in Great Britain. Mammal Rev 33(2):174-188 